\title{
Heritability, genetic gain, and correlations in cowpea beans (Vigna unguiculata [L.] (Walp.)
}

\section{Heredabilidad, ganancia genética y correlaciones en fríjol caupí (Vigna unguiculata [L.] (Walp.)}
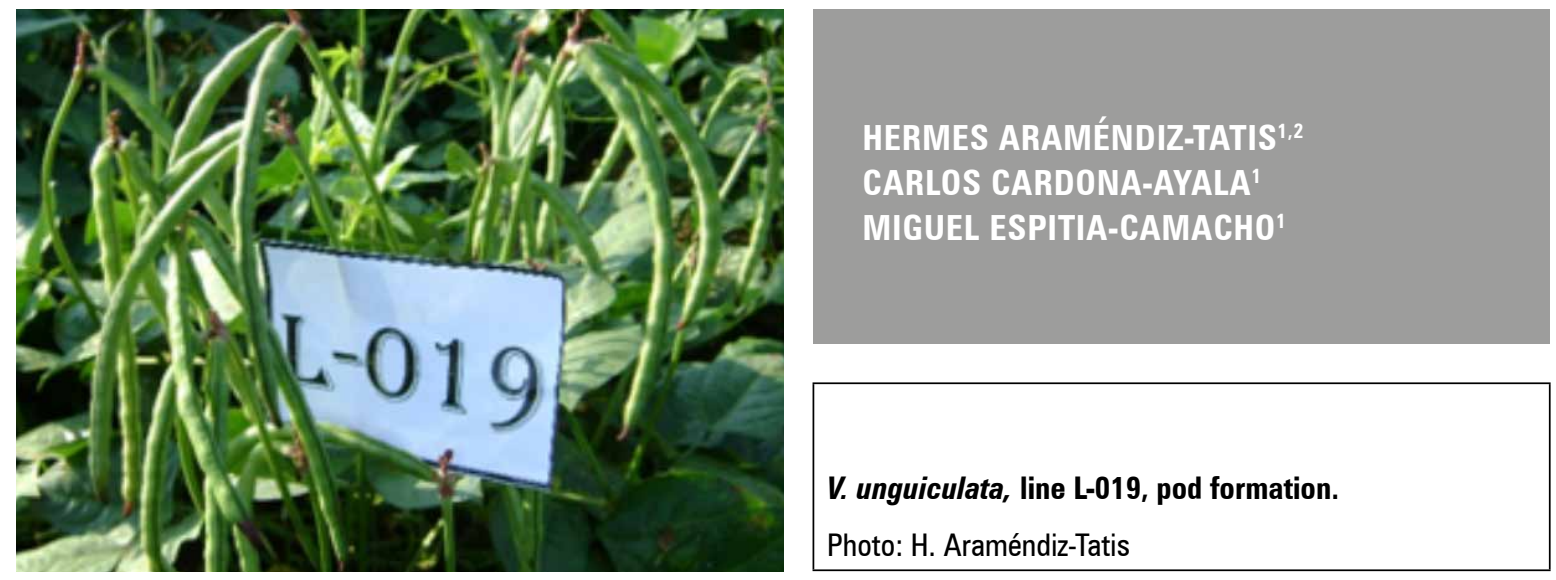

\begin{abstract}
Cowpea beans are the most important legume in the Caribbean region of Colombia. This grain is produced mainly by small farmers in rural agriculture but is becoming more important every year for commercial agriculture. The objective of this study was to estimate heritability, genetic gain and correlations between agronomic characteristics and the nutritional content of 30 cowpea bean cultivars. The number of days to flowering (NDF), number of pods per plant (NPP), number of pods per peduncle (NPPE), peduncle length (PEL), number of nodes on main stem (NNMS), grain length (GL), grain width (GW), weight of 100 seeds (W100S), iron content $(\mathrm{FeC})$, zinc content $(\mathrm{ZnC})$, protein content in percentage (PROT) and YIELD were evaluated. Likewise, the genetic parameters: phenotypic coefficient of variation (PCV), genotypic coefficient of variation (GCV), variability index (b), heritability $\left[\left(\mathrm{h}^{2}(\%)\right]\right.$, genetic gain (GG) and genetic progress (\%), together with phenotypic correlations and genetic correlations, were determined. Genetic variability was evidenced in the population $(P<0.05)$, except for PEL. The highest heritability was in W100S, ZnC and FeC $\left(\mathrm{h}_{\mathrm{A}} \mathrm{>}>96 \%\right)$. The greatest advance was achieved in $\mathrm{ZnC}, \mathrm{FeC}, \mathrm{W} 100 \mathrm{~S}$ and YIELD, with values higher than $30 \%$, indicating the potential use of the evaluated genotypes for improving this species and positive and significant phenotypic and genotypic correlations between YIELD and PROT. Therefore, cultivars with higher yields and protein contents can be obtained.
\end{abstract}

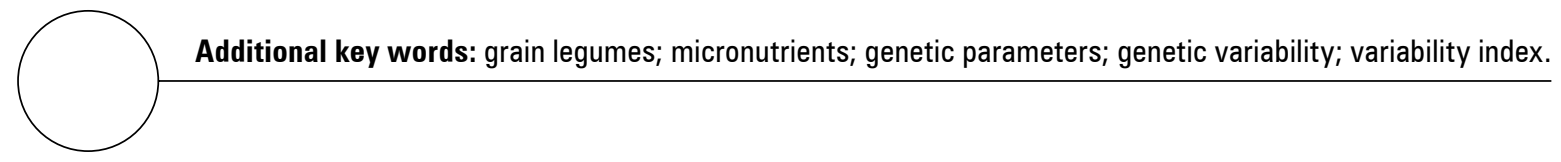

\footnotetext{
Universidad de Córdoba, Monteria (Colombia). ORCID Araméndiz-Tatis, H.: 0000-0002-2585-6273; ORCID Cardona-Ayala, C.E.: 0000-0002-9607-3858; ORCID Espitia-Camacho, M.: 0000-0001-7382-9643

2 Corresponding author. haramendiz@correo.unicordoba.edu.co
} 


\section{RESUMEN}

El fríjol caupí es la leguminosa más importante de la región Caribe de Colombia, cuyo grano es producido principalmente por pequeños productores en la agricultura campesina, pero que cada año cobra más importancia en la agricultura empresarial. El objetivo del estudio fue estimar heredabilidad, avance genético y correlaciones entre características agronómicas y contenido nutricional de 30 cultivares de fríjol caupí. Fueron evaluados los caracteres número de días a floración (NDF), número de vainas por planta (NVP), número de vainas por pedúnculo (NVPE), longitud del pedúnculo (LPE), número de nudos del tallo principal (NNTP), longitud del grano (LG), ancho del grano (AG), peso de 100 semillas (P100S), contenido de hierro (CFe), contenido de zinc (CZn), contenido de proteína en porcentaje (PROT) $(\% \mathrm{P})$ y rendimiento (REND). Así mismo, los parámetros genéticos: coeficiente de variación fenotípico $\left(\mathrm{CV}_{\mathrm{F}}\right)$, coeficiente de variación genotípico $(\mathrm{CVG})$, índice de variabilidad $(\mathrm{b})$, heredabilidad $\left[\left(\mathrm{h}^{2}(\%)\right]\right.$, ganancia genética, progreso genético genética en la población $(P<0,05)$, excepto para LPE. La heredabilidad más alta, en sentido amplio se presentó en P100S, CZn y CFe $\left(\mathrm{h}^{2}{ }_{\mathrm{A}}>96 \%\right)$. El mayor avance se logró en CZn, CFe, P100S y REND, con valores superiores al 30\%, lo que denota la posibilidad de hacer uso de los genotipos evaluados para mejorar la especie. Así mismo, correlaciones fenotípicas y genotípicas positivas y significativas entre REND y PROT, lo que posibilita la obtención de cultivares de mayor rendimiento y contenido de proteína.

Palabras clave adicionales: legumbres de grano; micronutrientes; parámetros genéticos; variabilidad genética; índice de variabilidad.

Received: 12-01-2021 Accepted: 03-03-2021 Published: 15-03-2021

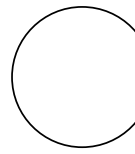

The cowpea bean (Vigna unguiculata (L.) Walp) is the second most cultivated legume in the world after common beans and had an area of 12,496,305 ha in 2018, with an average yield of $578 \mathrm{~kg} \mathrm{ha}^{-1}$, which makes it important in tropical and subtropical areas because of its protein content (20-25\%), iron (48-69 $\mathrm{mg} \mathrm{kg}^{-1}$ ) and zinc (29.9-41.8 $\left.\mathrm{mg} \mathrm{kg}^{-1}\right)$, mitigating the problems of hidden hunger in vulnerable families $(\mathrm{Da}$ Silva et al., 2017; Faostat, 2020). Also, it has the ability to adapt to water stress, high temperatures, soils with low fertility, such as with green manure, and crop rotation, especially with cereals, managing to fix between 40 to $80 \mathrm{~kg}$ of nitrogen per ha (Mafakheri et al., 2017).

In Colombia, it is cultivated in departments of the Caribbean region, where fresh or dry grain is consumed in various ways because of its rapid cooking, especially in recipes for rice with beans, soups, fritters, and stews, etc. (Araméndiz-Tatis et al., 2019).

The success of a genetic improvement program depends on the magnitude of the variability present in the available resources. In this way, the determination of the yield and its components is of vital importance, to know the genetic differences between the accessions and to plan the activities of a genetic improvement program in order to make a selection of parents with desirable genes. Then, hybridization can be used to obtain segregating populations and generational advancement with the selection of plants with excellent agronomic attributes that achieve planned objectives (Devi and Janamami, 2018). Nkoana et al. (2019) argued that morphological diversity plays an important role in the genetic improvement of plants since it satisfies the needs of farmers and consumers, especially for proteins, vitamins and minerals for vulnerable populations in rural and urban areas instead of meat, and complements diets rich in carbohydrates, such as cereals.

According to Weldemichael et al. (2017), genetic parameters such as the genotypic coefficient of variation (GCV) and the phenotypic coefficient of variation (PCV) are fundamental to understanding variability in a germplasm collection; while, heritability is associated with the efficiency of the selection on the phenotypic behavior of cultivars. However, this alone does not provide information for individual genotype selection, which is why the heritability associated with genetic advancement predicts the effect of selecting the best genotypes with respect to performance and nutritional contents. 
Studies on this species by Kumar et al. (2013) and Silva et al. (2014) reported that the studied populations had a potential for selection and gains from crosses in terms of the studied phenotypes in the evaluated characteristics.

The objective of the present research was to estimate the heritability, genetic advancement and correlations of the cowpea bean collection under the conditions of the Sinu Valley of Colombia to identify parents with desirable agronomic characteristics that significantly contribute to the improvement of yield and nutrient contents.

\section{MATERIALS AND METHODS}

This research was carried out in 2018 in Cerete-Colombia, at $8^{\circ} 54^{\prime} 45^{\prime \prime} \mathrm{N}$ and $75^{\circ} 48^{\prime} 33^{\prime \prime} \mathrm{W}$, altitude of $12 \mathrm{~m}$ a.s.l., with an average annual temperature of $27^{\circ} \mathrm{C}$ and average rainfall of $1,500 \mathrm{~mm}$. The soil has a loamy texture, with a slightly acidic $\mathrm{pH}, \mathrm{CEC}$ of $22.85 \pm 4.36 \mathrm{cmol}_{(+)} \mathrm{kg}^{-1}$, CE of $0.52 \pm 0.48 \mathrm{dS} \mathrm{cm}^{-1}$ and OM of $2.72 \pm 0.81 \%$ (Contreras-Santos et al., 2020).

The 30 genotypes are listed in table 1, identified according to their origin.

The experiment was carried out according to the recommendations for the agronomic management of cowpea beans in the Colombian Caribbean (Araméndiz-Tatis et al., 2019). The experiment design was randomized complete blocks, with 30 cultivars and four replications. The size of the experiment unit was two rows of $4 \mathrm{~m}$ in length, separated by a distance of $1.0 \mathrm{~m}$ between rows and $0.4 \mathrm{~m}$ between plants. The experiment area was $960 \mathrm{~m}^{2}$.

The measurement of response variables was carried out based on the descriptors proposed by IBPGR (1983). The registered characteristics were: number of days to flowering (NDF), number of pods per plant (NPP), number of pods per peduncle (NPPE), peduncle length (PEL), number of nodes on main stem (NNMS), grain length (GL), grain width (GW), weight of 100 seeds (W100S), iron content (FeC), zinc content $(\mathrm{ZnC})$, protein content in percentage (PROT) and YIELD.

Analysis of variance was performed for all traits, using the GENES program version 2016, 6.0, developed by Cruz (2016), with which the genetic parameters were estimated.
Table 1. Name and origin of cultivars.

\begin{tabular}{|c|c|c|}
\hline No. & Name & Origin \\
\hline 1 & Caupí Negro & Colombia \\
\hline 2 & Caupí Calamarí & Colombia \\
\hline 3 & Caupíca M-11 & Colombia \\
\hline 4 & Caupí Cuarentano & Colombia \\
\hline 5 & Caupí Provinciano & Colombia \\
\hline 6 & Caupí Betancí & Colombia \\
\hline 7 & Criollo Córdoba & Colombia \\
\hline 8 & L-CP-M-35 & Nigeria \\
\hline 9 & L-CP-M-37 & Nigeria \\
\hline 10 & BRS Milenium & Brasil \\
\hline 11 & IT 86 & Brasil \\
\hline 12 & TVU 382 & Brasil \\
\hline 13 & Gurgueia & Brasil \\
\hline 14 & BRS Guariba & Brasil \\
\hline 15 & BRS Potengi & Brasil \\
\hline 16 & BRS Tumucumaque & Brasil \\
\hline 17 & BRS Jurua & Brasil \\
\hline 18 & Caupí Brasil-2016 & Brasil \\
\hline 19 & MNC05-828C-3-15 & Brasil \\
\hline 20 & Judío Blanco & México \\
\hline 21 & 24135 & UNK \\
\hline 22 & Caupícor 50 & Colombia \\
\hline 23 & L 019 & Colombia \\
\hline 24 & LC 006-016 & Colombia \\
\hline 25 & Momposino & Colombia \\
\hline 26 & Mono Largo & Colombia \\
\hline 27 & Mano de Tigre & Colombia \\
\hline 28 & Guajiro & Colombia \\
\hline 29 & Capisuna & Colombia \\
\hline 30 & "Nuevo" & Colombia \\
\hline
\end{tabular}

Heritability in the broad sense $\left(\mathrm{h}^{2}{ }_{\mathrm{A}}\right)$ was estimated for each variable with the classic method, as described below:

$\mathrm{h}_{\mathrm{A}}^{2}=\left(\sigma_{\mathrm{G}}^{2} / \sigma_{\mathrm{F}}^{2}\right) * 100$

where, $\sigma_{G}^{2}$ was the mean genetic variance, and $\sigma_{F}^{2}$ was the mean phenotypic variance.

The genetic gain (GG) was estimated for each variable according to Johnson et al. (1955):

$G G=K \sigma_{F} h^{2}$ 
where, $k$ was the selection differential at $5 \%$ selection intensity, equivalent to 2.06; $\sigma_{F}$ was the phenotypic standard deviation; and $h^{2}$ was the heritability.

The genetic progress (GP) was also expressed as a percentage, according to Robinson et al. (1949), and classified as low, moderate and high (Johnson et al., 1955).

\section{RESULTS AND DISCUSSION}

\section{Analysis of variance}

The results of the analysis of variance are shown in table 2 . The genotypes showed highly significant differences $(P<0.01$ and $P<0.05)$, e except PEL, which showed genetic variability, which is interesting for genetic improvement programs since it selects the best genotypes according to the agronomic characteristics of interest; these results agree with those of Nkoana et al. (2019) and Ribeiro et al. (2019).

The coefficients of variation were less than $20 \%$, except for NPP, PEL and YIELD, without affecting the experiment precision, as noted by Silva and Neves (2011).

\section{Genetic parameters}

Table 3 shows the results for the parameters. The genetic variance (GV) was higher than the environmental variance (EV), which corroborates the results of the ANOVA and supports the usefulness of genetic improvement for plants and the fact that the phenotypic coefficient of variation (PCV) and genotypic coefficient of variation (GCV) ranged between $<10 \%$, 10 to $20 \%$ and $>20 \%$, considered low, medium and high, respectively (Getachew et al., 2015).

The PCVs had a greater magnitude than the GCVs, which means that the existing variation was not only due to genetic differences between the cultivars but also to environmental effects given the polygenic inheritance of these characteristics, as has been indicated by Nkoana et al. (2019) in cowpea beans.

Since genetic improvement is a function of the quantification of exploitable genetic variability (Keneni et al., 2011), genetic variance with a greater magnitude than the environmental variance in the studied traits (Tab. 3) means that the differences with a genetic origin, which was observed in the variation indices $b$, with values $\geq 1.0$ in NDF, GL, GW, W100S, FeC, $\mathrm{ZnC}$ and PROT, favorable for the selection (Moraes et al., 2014) of characteristics for breeding purposes (Mofokeng et al., 2020).

Table 2. Mean squares and statistical significance of the sources of variation for the characteristics in the $\mathbf{3 0}$ genotypes of cowpea beans.

\begin{tabular}{|c|c|c|c|c|}
\hline \multirow{2}{*}{ Characteristics } & \multicolumn{3}{|c|}{ Mean squares } & \multirow{2}{*}{ CV (\%) } \\
\hline & Genotypes & Replications & Error & \\
\hline Number of days to flowering (NDF) & $27.53^{* *}$ & 5.9 & 4.61 & 5.89 \\
\hline Number of pods per plant (NPP) & $24.15^{* *}$ & 30.32 & 10.88 & 24.65 \\
\hline Number of pods per peduncle (NPPE) & $0.20^{*}$ & 0.05 & 0.12 & 18.77 \\
\hline Peduncle length (PEL) (cm) & $0.27^{\mathrm{NS}}$ & 0.21 & 4.35 & 27.81 \\
\hline Number of nodes on main stem (NNMS) & $2.66^{* *}$ & 5.47 & 0.77 & 13.70 \\
\hline Grain length $(G L)(m m)$ & $2.70^{* *}$ & 0.12 & 0.14 & 4.19 \\
\hline Grain width $(\mathrm{GW})(\mathrm{mm})$ & $0.62^{* *}$ & 0.01 & 0.02 & 3.34 \\
\hline Weight of 100 seeds (W100S) (g) & $77.64^{* *}$ & 5.43 & 1.55 & 6.42 \\
\hline Yield (YIELD) (kg ha-1) & $1506482^{* *}$ & 2502903 & 522426 & 40.53 \\
\hline Iron content (FeC) $\left(\mathrm{mg} \mathrm{kg}^{-1}\right)$ & $356.17^{* *}$ & 5.23 & 12.14 & 6.14 \\
\hline Zinc content (ZnC) $\left(\mathrm{mg} \mathrm{kg}^{-1}\right)$ & $253.58^{* *}$ & 12.54 & 5.86 & 4.59 \\
\hline Protein (PROT) (\%) & $13.18^{* *}$ & 10.47 & 1.75 & 6.28 \\
\hline Degrees of freedom & 29 & 3 & 87 & \\
\hline
\end{tabular}

${ }^{*}$ * significant at $P<0.01,{ }^{*}$ significant at $P<0.05$, Ns not significant, CV (\%), coefficient of variation. 
Table 3. Phenotypic variance (PV), genotypic variance (GV), environmental variance (EV), genotypic coefficient of variation
(GCV), phenotypic coefficient of variation (PCV), variability index (b), heritability in the broad sense (h²), genetic gain
(GG) and genetic progress as percentage of mean (GPM).

\begin{tabular}{|l|c|c|c|c|c|c|c|c|c|c|}
\hline Characteristics & Mean & PV & GV & EV & PCV (\%) & GCV (\%) & b & $h^{2}(\%)$ & GA & GAM (\%) \\
\hline NDF & 36.48 & 6.88 & 5.72 & 1.15 & 7.19 & 6.56 & 6.56 & 83.22 & 4.48 & 12.29 \\
\hline NPP & 13.38 & 6.03 & 3.32 & 2.72 & 18.36 & 13.60 & 0.55 & 54.92 & 2.77 & 20.76 \\
\hline NPPE & 1.85 & 0.05 & 0.03 & 0.02 & 12.31 & 7.59 & 0.40 & 39.56 & 0.18 & 9.85 \\
\hline PEL (cm) & 1.68 & 0.068 & 0.013 & 0.054 & 15.52 & 6.78 & 0.24 & 19.56 & 0.09 & 5.33 \\
\hline NNMS & 6.44 & 0.666 & 0.471 & 0.194 & 12.67 & 10.66 & 0.77 & 70.76 & 1.18 & 18.47 \\
\hline GL (mm) & 9.02 & 0.675 & 0.639 & 0.035 & 9.11 & 8.86 & 2.11 & 94.69 & 1.60 & 17.77 \\
\hline GW (mm) & 5.16 & 0.156 & 0.149 & 0.007 & 7.66 & 7.48 & 2.23 & 95.24 & 0.77 & 15.04 \\
\hline W100S (g) & 19.41 & 19.41 & 19.02 & 0.38 & 22.69 & 22.47 & 3.49 & 97.99 & 8.89 & 45.81 \\
\hline YIELD (kg) & 1782 & 376620.56 & 246013.93 & 130606.63 & 34.42 & 27.81 & 0.68 & 65.32 & 8.25 & 46.34 \\
\hline FeC (mg kg-1) & 56.71 & 89.04 & 86.00 & 3.03 & 16.63 & 16.35 & 2.66 & 96.58 & 18.77 & 33.10 \\
\hline ZnC (mg kg-1) & 52.73 & 63.39 & 61.92 & 1.46 & 15.09 & 14.92 & 3.24 & 97.68 & 16.02 & 30.38 \\
\hline PROT (\%) & 21.08 & 3.29 & 2.85 & 0.43 & 8.61 & 8.01 & 1.27 & 86.55 & 3.24 & 15.37 \\
\hline
\end{tabular}

$\mathrm{NDF}=$ number of days to flowering; NPP = number of pods per plant; NPPE = number of pods per peduncle; PEL= peduncle length; NNMS: number of nods on main stem; $\mathrm{GL}=$ grain length: $\mathrm{GW}=$ grain width; $\mathrm{W} 100 \mathrm{~S}=$ weight of 100 seeds; $\mathrm{FeC}=$ Iron content; $\mathrm{ZnC}=$ Zinc content; $\mathrm{PROT}=$ protein content.

The characteristics with a high and moderate PCV and GCV included NPP, NNMS, W100S, YIELD, FeC and $\mathrm{ZnC}$ (Tab. 3), similar to that obtained by Gerrano et al. (2015) and Mofokeng et al. (2020), suggesting they can be significantly improved through selection, as argued by Mendonça et al. (2018).

The heritability estimates in the broad sense ranged between 19.56 and $97.99 \%$, with more than 80\% for NDF, GL, GW, W100S, FeC, ZnC and PROT and lower values (50 to 70\%) for NPP, NNMS and YIELD, indicating the existence of genetic variability between cultivars. According to Nkoana et al. (2019) and Mofokeng et al. (2020), these heritability values mean the phenotype exhibited a high expression in the genotype, indicating good efficiency of selection and genetic gain, which must be demonstrated with the selection of the best genotypes.

The genetic progress (GPM) percentage showed values of $5.33 \%$ for PEL, a low value, with 45.81 for W100S and 46.34\% for YIELD, high values. According to Ubi et al. (2001), high heritability values associated with higher percentages of genetic progress indicate the predominance of genes with additive action and much easier selection.

Low heritability and genetic gain were observed in PEL and NPPE, while high heritability and moderate genetic gain were estimated for PROT. Combinations of genetic parameters can be attributed to genes with non-additive gene action (Ara et al., 2009). Therefore, a cross between parents with complementary characteristics will obtain progenies with better grain yields and micronutrient contents.

\section{Correlations}

The study of the interrelation between several characters in the form of correlation is one of the very important aspects in the genetic improvement of plants, so that the breeder is very efficient in selections based on correlation and uncorrelated responses (Agrawal et al., 2018).

The values of the genotypic correlations $(\mathrm{rG})$ had the same tendency and superior to the phenotypic correlations $(\mathrm{rF})$ (Tab. 4), which indicated that the relationship between the variables was based on additive genetic effects. Preliminary results have been reported by Andrade et al. (2010) and Silva et al. (2014) in cowpea beans and by Agrawal et al. (2018) in chickpeas, who argued that phenotypic selection can be efficient.

There were negative phenotypic and genotypic correlations $(P<0.01)$ between NDF and NNMS, that is, as phylochron decreased, NDF increased, indicating that early cultivars form leaves more quickly than 
late ones. In addition, NDF had positive phenotypic and genotypic correlations with YIELD $(P<0.05)$, i.e., later cultivars have the potential of generating higher yields because of an increased number of branches, which favors the development of a greater number of pods per plant (Ferrari et al., 2018; Meena et al., 2015).

NPP correlated phenotypically $(P<0.05)$, genotypically $(P<0.01)$ and positively with NNMS because pods are produced from the differentiation of flower buds in the stem nodes. However, the phenotypic $(P<0.05)$ and genotypic $(P<0.01)$ correlations of NPP with GW were negative, which was due to the fact that a higher NPP means GW decreases, along with PEL and W100S. The plants distribute photoassimilates to the organs in formation, in proportion to demand, which depends on the number of organs in development. Similar results were found by
Mendonça et al. (2018). The lack of significance of the correlation between NPP and YIELD could have been overshadowed by phenotypic plasticity in the face of environmental effects on polygenic characteristics (Ferrari et al., 2018).

NPPE registered positive phenotypic and genotypic correlations $(P<0.01)$ and $(P<0.05)$ with NNMS and $\mathrm{FeC}$. The increase in NPPE was associated with an increase in NNMS and, simultaneously, with an increase in $\mathrm{FeC}$ in the seeds. The higher the rate of leaf emission, the greater the accumulation of iron in the seed by translocation despite the fact that it is not very mobile element in the plant. Furthermore, a higher NNMS could lead to the formation of a greater number of productive branches (Kinhoégbè et al., 2020). On the other hand, the negative phenotypic and genotypic correlations $(P<0.01)$ between NPPE

Table 4. Estimates of the phenotypic and genotypic correlation matrix in cowpea bean characteristics.

\begin{tabular}{|c|c|c|c|c|c|c|c|c|c|c|c|c|}
\hline VAR'S & r's & NPP & NPPE & PEL & NNMS & $\mathrm{GL}$ & GW & YIELD & W100S & $\mathrm{FeC}$ & $\mathrm{ZnC}$ & PROT \\
\hline \multirow{2}{*}{ NDF } & $\mathrm{rF}$ & -0.15 & -0.24 & 0.32 & $-0.53^{* *}$ & 0.03 & -0.06 & $0.40^{*}$ & -0.13 & 0.07 & -0.11 & 0.12 \\
\hline & $\mathrm{rG}$ & -0.19 & $-0.47^{* *}$ & $0.73^{* *}$ & $-0.60^{* *}$ & 0.04 & -0.08 & $0.52^{* *}$ & -0.13 & 0.08 & -0.11 & 0.14 \\
\hline \multirow{2}{*}{ NPP } & $\mathrm{rF}$ & & 0.23 & -0.07 & $0.45^{*}$ & -0.07 & $-0.42^{*}$ & 0.16 & -0.28 & -0.05 & 0.24 & 0.13 \\
\hline & $r G$ & & 0.26 & $-0.51^{* *}$ & $0.60^{* *}$ & -0.10 & $-0.60^{* *}$ & 0.03 & $-0.40^{*}$ & -0.06 & 0.32 & 0.16 \\
\hline \multirow{2}{*}{ NPPE } & $\mathrm{rF}$ & & & $-0.36^{*}$ & $0.62^{* *}$ & $-0.45^{*}$ & $-0.37^{*}$ & 0.21 & $-0.47^{* *}$ & $0.43^{*}$ & 0.09 & 0.16 \\
\hline & $r G$ & & & $-1.00^{* *}$ & $1.00^{* *}$ & $-0.73^{* *}$ & $-0.56^{* *}$ & 0.34 & $-0.77^{* *}$ & $0.72 * *$ & 0.13 & 0.34 \\
\hline \multirow{2}{*}{ PEL } & $\mathrm{rF}$ & & & & -0.35 & 0.19 & 0.05 & 0.03 & 0.13 & -0.03 & -0.07 & -0.06 \\
\hline & $r G$ & & & & $-0.98^{* *}$ & $0.41^{*}$ & 0.04 & 0.01 & 0.31 & -0.13 & -0.21 & -0.23 \\
\hline \multirow{2}{*}{ NNMS } & $\mathrm{rF}$ & & & & & -0.24 & -0.22 & 0.15 & -0.21 & -0.06 & 0.18 & 0.30 \\
\hline & $\mathrm{rG}$ & & & & & -0.30 & -0.25 & 0.11 & -0.26 & -0.08 & 0.22 & $0.43^{*}$ \\
\hline \multirow{2}{*}{ GL } & $\mathrm{rF}$ & & & & & & $0.59 * *$ & -0.22 & $0.86^{* *}$ & $-0.39^{*}$ & -0.24 & 0.04 \\
\hline & $\mathrm{rG}$ & & & & & & $0.60^{* *}$ & -0.29 & $0.88^{* *}$ & -0.41 & -0.25 & 0.06 \\
\hline \multirow{2}{*}{ GW } & $\mathrm{rF}$ & & & & & & & -0.35 & $0.83^{* *}$ & -0.34 & -0.13 & -0.25 \\
\hline & $\mathrm{rG}$ & & & & & & & -0.43 & $0.85^{* *}$ & -0.36 & -0.14 & -0.27 \\
\hline \multirow{2}{*}{ YIELD } & $\mathrm{rF}$ & & & & & & & & -0.33 & -0.14 & -0.23 & $0.49^{* *}$ \\
\hline & $\mathrm{rG}$ & & & & & & & & $-0.43^{*}$ & -0.19 & -0.29 & $0.70^{* *}$ \\
\hline \multirow{2}{*}{ W100S } & $\mathrm{rF}$ & & & & & & & & & $-0.46^{*}$ & -0.19 & -0.13 \\
\hline & $\mathrm{rG}$ & & & & & & & & & $-0.48^{* *}$ & -0.19 & -0.13 \\
\hline \multirow{2}{*}{$\mathrm{FeC}$} & $\mathrm{rF}$ & & & & & & & & & & 0.21 & -0.08 \\
\hline & $\mathrm{rG}$ & & & & & & & & & & 0.21 & -0.08 \\
\hline \multirow{2}{*}{$\mathrm{ZnC}$} & $\mathrm{rF}$ & & & & & & & & & & & 0.10 \\
\hline & $r G$ & & & & & & & & & & & 0.11 \\
\hline
\end{tabular}

VAR'S = variables; $r^{\prime}$ s = correlations; $r F=$ phenotypic correlations; $r G=$ genotypic correlations; $N D F=$ number of days to flowering; $N P P=$ number of pods per plant; $\mathrm{NPPE}=$ number of pods per peduncle; $\mathrm{PEL}=$ peduncle length; NNMS: number of nods on main stem; $\mathrm{GL}=$ grain length: $\mathrm{GW}=$ grain width; $\mathrm{W} 100 \mathrm{~S}=$ weight of 100 seeds; YIELD; FeC = Iron content; ZnC $=$ Zinc content; PROT = protein content; ${ }^{*}$ significant at $P<0.05$; ${ }^{* *}$ : significant at $P<0.01$. 
and PEL, GL, GW and W100S showed that, when NPPE is increased, along with NPP, the supply of photoassimilates to the seeds increases. This competition reduces the agronomic value of characteristics that could be used as selection criteria (MathosFilho et al., 2009).

PEL had a negative genotypic correlation $(P<0.01)$ with NNMS but a positive one with GL $(P<0.05)$. This indicates that a higher GL is associated with a higher PEL, but the latter characteristic is associated with a lower NPP and NPPE. In addition, the selection of a higher PEL would compromise commercial performance since a higher PEL, together with the weight of the pods, would lead to greater contact with the soil, with a consequent deterioration because of the influence of the microclimate on the lower part of the plant.

NNMS was only genotypically correlated with PROT $(P<0.05)$. This indicates that as more knots originate, the rate of leaf formation increases and therefore protein accumulates in the seeds, which suggests that it is possible to select plants with higher NNMSs, with greater accumulation of protein in the seeds.

GL and GW registered positive phenotypic and genotypic correlations $(P<0.01)$ with W100S, that is, the heavier seeds were larger, as expected because of their allometry. On the other hand, the negative correlation between GL and FeC $(P<0.05)$ showed that longer grains have decreased iron contents, possibly because, when the size of the organ longitudinally increases, the accumulation of iron decreases because of the low mobility of iron.

YIELD did not have a correlation with $\mathrm{FeC}$ and $\mathrm{ZnC}$, which agreed with the results obtained by Singh et al. (2018). For the development of cultivars with higher yields and high micronutrient and protein contents, cultivars should be submitted to genetic studies to find quantitative trait loci ( $\mathrm{QTL}$ ) for $\mathrm{Fe}, \mathrm{Zn}$, protein and high yield contents (Gerrano et al., 2018; Gondwe et al., 2019). In this study, YIELD presented positive phenotypic and genotypic correlations $(P<0.01)$ with PROT, indicating that it is possible to find high yield and protein contents simultaneously. This contradicts the results of Moura et al. (2012), who reported a negative correlation between yield and protein contents. On the other hand, YIELD presented a negative correlation with W100S $(P<0.05)$, coinciding with the result of Silva and Neves (2011), so an improvement in performance through P100S is not possible.

\section{CONCLUSIONS}

There is genetic variability in the population of 30 cowpea bean cultivars that can be exploited in genetic improvement for characteristics of agronomic interest and for nutritional contents.

A high heritability was observed in the characteristics NDF, GL, GW, W100S, FeC, ZnC and PROT, while a high genetic advancement was seen in YIELD, W100S, FeC and $\mathrm{ZnC}$, along with positive phenotypic and genotypic correlations between YIELD and PROT, which allow for the parallel improvement of yield and protein percentage, which are associated with iron and zinc contents.

Conflict of interests: The manuscript was prepared and reviewed with the participation of the authors, who declare that there exists no conflict of interest that puts the validity of the presented results at risk.

\section{BIBLIOGRAPHIC REFERENCES}

Agrawal, T., A. Kumar, S. Kumar, A. Kumar, R. Kumar, S. Kumar, and P.K. Singh. 2018. Correlation and path coefficient analysis for grain yield and yield components in chickpea (Cicer arietinum L.) under normal and late sown conditions of Bihar, India. Int. J. Curr. Microbiol. App. Sci. 7(2), 1633-1642. Doi: 10.20546/ ijcmas.2018.702.197

Andrade, F.N., M. Moura Rocha, R.L. Gomes, F. Freire Filhoe, and S.R. Ramo. 2010. Estimativas de parâmetros genéticos em genótipos de feijão-caupi avaliados para feijão fresco. Rev. Ciênc. Agron. 41(2), 253-258. Doi: 10.1590/S1806-66902010000200012

Ara, A., R. Narayan, N. Ahmed, and S.H. Khan. 2009. Genetic variability and selection parameters for yield and quality attributes in tomato. Indian J. Hort. 66(1), 73-78.

Araméndiz-Tatis, H., C. Cardona-Ayala, A. Jarma, E. Combatt, J. Jaraba, T. Mercado, M. Espitia-Camacho, C. de Paula, Y. Pastrana, and J. Hernández. 2019. Manejo agronómico del fríjol caupí en el Caribe colombiano. Universidad de Córdoba, Montería, Colombia.

Contreras-Santos, J.L., J. Martínez-Atencia, J. Cadena-Torres, R.S. Novoa-Yánez, and R. Tamara-Morelos. 2020. Una evaluación de las propiedades fisicoquímicas de suelo en sistema productivo de maíz - algodón y arroz en el Valle del Sinú en Colombia. Rev. UDCA Act. Divulg. Cient. 23(2), e1375. Doi: 10.31910/rudca.v23. n2.2020.1375

Cruz, C.D. 2016. Programa Genes V.2014.6.1 - Aplicativo computacional em genética e estatística. In: http:// www.ufv.br/dbg/genes/genes.htm; consulted: September, 2016. 
Da Silva, D.O., C.A. Santos, S.L. Seido, W.L. Coelho, and D.A. Aquino. 2017. Retention of proteins and minerals after cooking in cowpea genotypes. Pesq. Agropec. Trop. 47(3), 353-359. Doi: 10.1590/1983-40632016v4747261

Devi, S.M. and P. Jayamani. 2018. Genetic variability, heritability, genetic advance studies in cowpea germplasm [Vigna unguiculata (L.) Walp.]. Electron. J. Plant Breed. 9(2), 476-481. Doi: 10.5958/0975-928X.2016.00050.8

Faostat. 2020. Crops. In: http://www.fao.org/statistics/ es/; consulted, June, 2020.

Ferrari, M., I.C. Carvalho, A.J. Pelegrin, M. Nardino, V.J. Szareski, T. Olivoto, T. Rosa, D.N. Follmann, C. Pegoraro, L.C. Maia, and V.O. Souza. 2018. Path analysis and phenotypic correlation among yield components of soybean using environmental stratification methods. Aust. J. Crop Sci. 12(02), 193-202. Doi: 10.21475/ ajcs.18.12.02.pne488

Gerrano, A.S., P.O. Adebola, W.S. Rensburgand, and S.M. Laurie. 2015. Geneticvariability in cowpea (Vigna unguiculata (L.) Walp.) genotypes. S. Afr. J. Plan. Soil 32(3), 165-174. Doi: 10.1080/02571862.2015.1014435

Gerrano, A.S., W.S. Rensburg, S.L. Venter, N.G. Shargie, B.A. Amelework, H.A. Shimelis, and M.T. Labuschagne. 2018. Selection of cowpea genotypes based on grain mineral and total protein content. Acta Agric. Scand. B Soil Plant Sci. 69(2), 155-166. Doi: 10.1080/09064710.2018.1520290

Getachew, T., M. Firew, F. Asnake, and E. Million. 2015. Genotype $\mathrm{x}$ environment interaction and stability analysis for yield and yield related traits of Kabuli-type Chickpea (Cicer arietinum L.) in Ethiopia. Afr. J. Biotech. 14(18), 1564-1575. Doi: 10.5897/AJB2014.14320

Gondwe, T.M., B.O. Alamu, P. Mdziniso, and P. Maziya-Dixon. 2019. Cowpea (Vigna unguiculata (L.) Walp) for food security: an evaluation of end-user traits of improved varieties in Swaziland. Sci. Rep. 9(1), 15991. Doi: 10.1038/s41598-019-52360-w

IBPGR, International Board for Plant Genetic Resources. 1983. Cowpea descriptors. Rome.

Johnson, H.W., H.F. Robinson, and R.E. Comstock. 1955. Estimates of genetic and environmental variability in soybeans. Agron. J. 47(7), 314-318. Doi: 10.2134/agro nj1955.00021962004700070009x

Keneni, G., E. Bekele, M. Imtiaz, D. Dagne, E. Getu, and F. Assefa. 2011. Genetic diversity and population structure of ethiopian chickpea (Cicer arietinum L.) germplasm accessions from different geographical origins as revealed by microsatellite markers. Plant Mol. Biol. Rep. 30(3), 654-665. Doi: 10.1007/s11105-011-0374-6

Kinhoégbè, G., G. Djèdatin, L. Loko, R. Agbo, R. Saxena, R. Varshney, R. Agbangla, and A. Dansi. 2020. Agro-morphological characterization of pigeonpea (Cajanus cajan L. Millspaugh) landraces grown in
Benin: Implications for breeding and conservation. J. Plant Breed. Crop Sci. 12(1), 34-49. Doi: 10.5897/ JPBCS2019.0836

Kumar, K.P., R.N. Kumar, T. Muneeswari, R. Lamror, and R. Kumari. 2013. Morphological and genetic variation studies in cowpeagenotypes [Vigna unguiculata (1.)] Walp. Legume Res. 36 (4), 351-354.

Mafakheri, K., M.R. Bihamta, and A.R. Abbasi. 2017. Assessment of genetic diversity in cowpea (Vigna unguiculata L.) germplasm using morphological and molecular characterization. Cogent Food Agric. 3(1), 1-9. Doi: 10.1080/23311932.2017.1327092

Mathos Filho, C.H., R. Ferreira Gomes, M. Moura Rocha, F. Freire Filho, and A.C. Lopes. 2009. Potencial produtivo de progênies de feijão-caupi com arquitectura ereta de planta. Ciênc. Rural 39(2), 348-354. Doi: 10.1590/ S0103-84782009000200006

Meena, H.K., K. Ram Krishna, and B. Singh. 2015. Character associations between seed yield and its components traits in cowpea [Vigna unguiculata (L.) Walp.]. Indian J. Agric. Res. 49(6), 567-570. Doi: 10.18805/ ijare.v49i6.6688

Mendonça, S.A., P.M. Bebe, S. Nascimento, V.B. Santos, and J.D. Marinho. 2018. Importance and correlations of characters for cowpea diversity in traditional varieties. Rev. Ciênc. Agron. 49(2), 267-274. Doi: 10.5935/1806-6690.20180030

Mofokeng, M.A., J. Mashilo, P. Rantso, and H. Shimelis. 2020. Genetic variation and genetic advance in cowpea based on yield and yield-related traits. Acta Agric. Scand. B Soil Plant Sci. 70(5), 381-391. Doi: 10.1080/09064710.2020.1749295

Moraes, C., B. Fernandes, L. Teixeira, L. Zimback, T.E. Vagne, R. Chaves, M. Moraes, and E. Mori. 2014. Estimativas dos parâmetros genéticos para seleção de árvores de eucalyptus. Sci. For. 42(104), 623-629.

Moura, J.O., M. Moura, R.L. Ferreira, F. Rodrigues-Freire, K. Damasceno, E. Silva, and V. Queiroz Ribeiro. 2012. Path analysis of iron and zinc contents and others traits in cowpea. Crop Breed. Appl. Biotechnol. 12(4), 245-252. Doi: 10.1590/S1984-70332012000400003

Nkoana, D.K., A.S. Gerrano, and E.T. Gwata. 2019. Agronomic performance and genetic variability of cowpea (Vigna unguiculata) accessions. Legum. Res. 42(6), 757-762.

Ribeiro, L.P., J.S. Pinto, M. Brandão, A. Mayrink, I. Ferreira, E. Vitorio, P.E. Teodoro, and L.L. Behering. 2019. Estimates of genetic divergence in cowpea by multivariate analysis in different environments. Biosci. J. 35(6), 1681-1687. Doi: 10.14393/BJ-v35n6a2019-42406

Robinson, H., R.E. Comstock, and V.H. Harvey. 1949. Estimates of heritability and degree of dominance in corn. Agron. J. 41(8), 353-359. Doi: 10.2134/ agronj1949.00021962004100080005x 
Silva, A., O.M. Morais, J.L. Santos, L.O. d'Arede, C.J. Silva, and M.M. Rocha. 2014. Estimativa de parâmetros genéticos em Vigna unguiculata. Rev. Ciênc. Agrár. 37(4), 399-407.

Silva, J.A. and J.A. Neves. 2011.Componentes de produção e suas correlações em genótipos de feijão-caupi em cultivo de sequeiro e irrigado. Rev. Ciênc. Agron. 42(3), 702-713. Doi: 10.1590/S1806-66902011000300017

Singh, R., A. Van Heusden, R. Kumar, and R. Visser. 2018. Genetic variation and correlation studies between micronutrient (Fe and $\mathrm{Zn}$ ), protein content and yield attributing traits in mung bean (Vigna. radiata L.). Legum. Res. 41(2), 167-174. Doi: 10.18805/lr.v0i0.7843

Ubi, E.B., H. Mignouna, and G. Obigbesan. 2001. Segregation for seed weight, pod length and days to flowering following cowpea cross. Afr. Crop Sci. J. 9(1), 463-470. Doi: $10.4314 /$ acsj.v9i3.27592

Weldemichael, G., S. Alamerew, and T. Kuf. 2017. Genetic variability, heritability, and genetic advance for quantitative traits in coffee (Coffea arabica L.) accessions in Ethiopia. Afr. J. Agric. Res. 12(21), 1824-1831. Doi: 10.5897/AJAR2016.12059 